PREPARED FOR THE U.S. DEPARTMENT OF ENERGY, UNDER CONTRACT DE-AC02-76CH03073

PPPL-3575

PPPL-3575

UC-70

Upgrades to the 4-Strap ICRF Antenna in Alcator C-Mod

G. Schilling, J.C. Hosea, J.R. Wilson, W. Beck, R.L. Boivin, P.T. Bonoli, D. Gwinn, W.D. Lee, E. Nelson-Melby, M. Porkolab, R. Vieira, S.J. Wukitch, and J.A. Goetz

June 2001
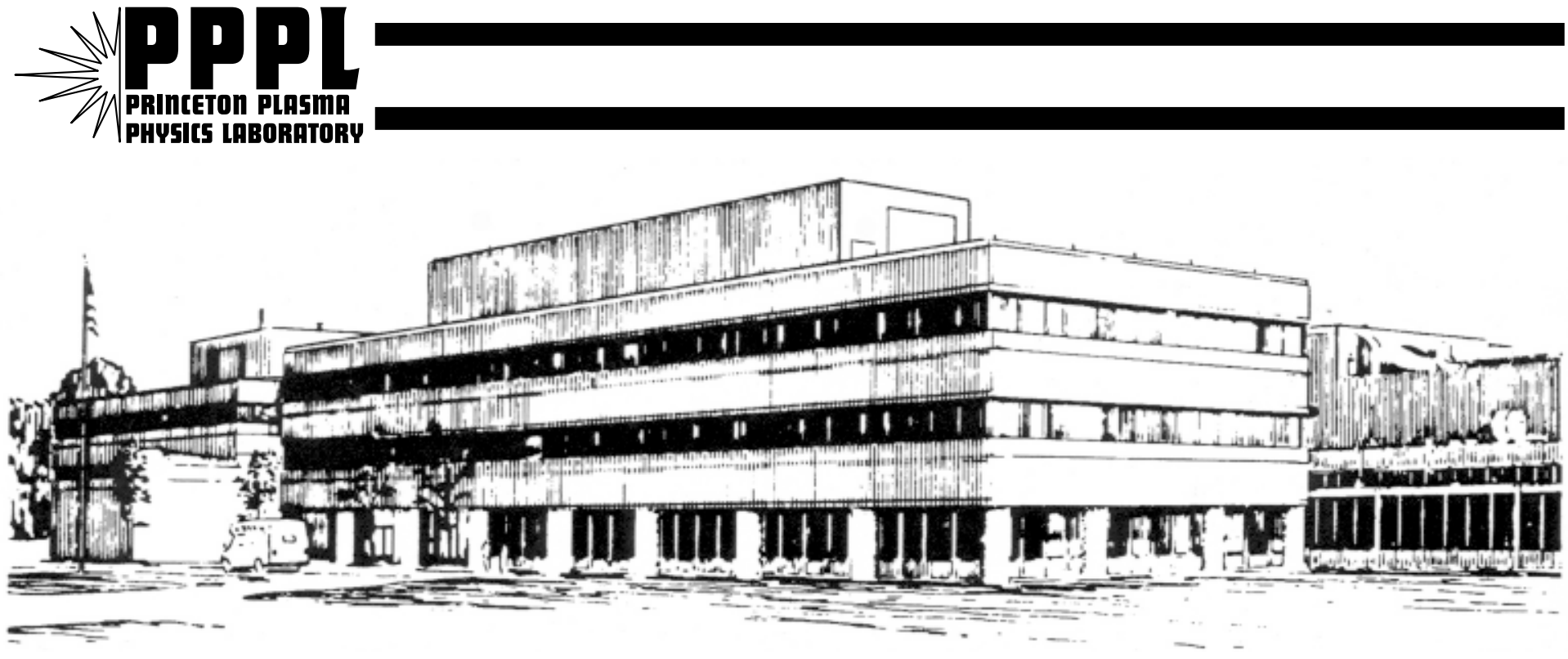

PRINCETON PLASMA PHYSICS LABORATORY PRINCETON UNIVERSITY, PRINCETON, NEW JERSEY 


\section{PPPL Reports Disclaimer}

This report was prepared as an account of work sponsored by an agency of the United States Government. Neither the United States Government nor any agency thereof, nor any of their employees, makes any warranty, express or implied, or assumes any legal liability or responsibility for the accuracy, completeness, or usefulness of any information, apparatus, product, or process disclosed, or represents that its use would not infringe privately owned rights. Reference herein to any specific commercial product, process, or service by trade name, trademark, manufacturer, or otherwise, does not necessarily constitute or imply its endorsement, recommendation, or favoring by the United States Government or any agency thereof. The views and opinions of authors expressed herein do not necessarily state or reflect those of the United States Government or any agency thereof.

\section{Availability}

This report is posted on the U.S. Department of Energy's Princeton Plasma Physics Laboratory Publications and Reports web site in Calendar Year 2001. The home page for PPPL Reports and Publications is: http://www.pppl.gov/pub_report/

DOE and DOE Contractors can obtain copies of this report from:

U.S. Department of Energy

Office of Scientific and Technical Information

DOE Technical Information Services (DTIS)

P.O. Box 62

Oak Ridge, TN 37831

Telephone: (865) 576-8401

Fax: (865) 576-5728

Email: reports@adonis.osti.gov

This report is available to the general public from:

National Technical Information Service

U.S. Department of Commerce

5285 Port Royal Road

Springfield, VA 22161

Telephone: 1-800-553-6847 or

(703) 605-6000

Fax: (703) 321-8547

Internet: http://www.ntis.gov/ordering.htm 


\title{
Upgrades to the 4-strap ICRF Antenna in Alcator C-Mod
}

\author{
G. Schilling ${ }^{1}$, J. C. Hosea ${ }^{1}$, J. R. Wilson ${ }^{1}$, W. Beck ${ }^{2}$, R. L. Boivin ${ }^{2}$, \\ P. T. Bonoli ${ }^{2}$, D. Gwinn ${ }^{2}$, W. D. Lee ${ }^{2}$, E. Nelson-Melby ${ }^{2}$, \\ M. Porkolab ${ }^{2}$, R. Vieira ${ }^{2}$, S. J. Wukitch ${ }^{2}$, J. A. Goetz ${ }^{3}$ \\ ${ }^{1}$ Princeton University Plasma Physics Laboratory, Princeton NJ 08543, \\ ${ }^{2}$ MIT Plasma Science and Fusion Center, Cambridge, MA 02139 \\ ${ }^{3}$ Physics Department, University of Wisconsin, Madison, WI 53706
}

\begin{abstract}
A 4-strap ICRF antenna suitable for plasma heating and current drive has been designed and fabricated for the Alcator C-Mod tokamak. Initial operation in plasma was limited by high metallic impurity injection resulting from front surface arcing between protection tiles and from current straps to Faraday shields. Antenna modifications were made in $2 / 2000$, resulting in impurity reduction, but low heating efficiency was observed when the antenna was operated in its 4-strap rather than a 2-strap configuration. Further modifications were made in 7/2000, with the installation of BN plasma-facing tiles and radiofrequency bypassing of the antenna backplane edges and ends to reduce potential leakage coupling to plasma surface modes. Good heating efficiency was now observed in both heating configurations, but coupled power was limited to $2.5 \mathrm{MW}$ in H-mode, $3 \mathrm{MW}$ in L-mode, by plasma-wall interactions. Additional modifications were started in 2/2001 and will be completed by this meeting. All the above upgrades and their effect on antenna performance will be presented.
\end{abstract}

\section{ANTENNA DESIGN}

The antenna design represents an attempt to provide four vertical current straps in a configuration that allows efficient heating as well as providing a directed launched wave spectrum for current drive by modifying the current strap phasing externally. A compact, segmented design was worked out that matched the toroidal and poloidal plasma curvature and was capable of being passed

through the $20 \mathrm{~cm}$ wide vacuum vessel ports and assembled in situ. Active elements and feeds were designed to handle up to $4 \mathrm{MW}$ power input. The antenna was installed in C-Mod in December, 1998, following checkout and conditioning in vacuum up to $45 \mathrm{kV}$ on the PPPL rf test stand. 


\section{FRONT SURFACE PLASMA-RF INTERACTIONS}

Initial operation during July-December 1999 resulted in serious antenna arcing accompanied by high levels of metallic impurity influx at heating power levels above $\sim 1.3 \mathrm{MW}$. The antenna had been designed with segmented plasma protection tiles at the top and bottom to simplify installation, but the segment to segment impedance at the ICRF driving frequency was sufficiently high to develop a voltage capable of arcing across these gaps under the local edge plasma conditions. Stainless steel straps were installed underneath the plasma protection tiles to short the tile gaps during the vacuum vessel opening in February, 2000, and have eliminated this problem.

The antenna's plasma protection tiles were changed from the original molybdenum to boron nitride to eliminate any remaining possible sources of metallic impurities during the July-August, 2000, opening. No deleterious effects on plasma operation resulting from the boron nitride have been observed.

Antenna operation from September to December, 2000, revealed a new front surface interaction limit. Operation above $2.5 \mathrm{MW}$ with $(0, \pi, 0, \pi)$ heating phasing led to impurity injection that caused a discharge disruption. Camera images of ICRF operation revealed antenna side and corner hot spots that were aligned along the edge magnetic field lines. Inspection in January, 2001, revealed slight misalignment of the protection tiles and exposed metal surfaces. An analysis of the hot spot mechanism suggests that the tokamak's field line pitch in front of the antenna results in nonzero rf magnetic flux linkage to tokamak field lines connecting antenna surfaces. The resulting rf electric field expels electrons, and plasma neutrality results in ion acceleration leading to an enhanced sheath potential. During the January-April, 2001, opening all front protection tiles were realigned with side tiles, all exposed metal surfaces were covered with boron nitride or removed, and a central boron nitride septum was installed to reduce the tokamak field line connection length.

\section{INTERNAL PLASMA-RF INTERACTIONS}

The February, 2000, opening revealed arcing along the direction of the tokamak magnetic field between the high voltage portion of the antenna current straps and adjacent resistive terminations of the Faraday shields. Grounded stainless steel cups were placed around the base of the Faraday shield rods to protect the resistive terminations. Subsequent inspections showed no damage.

All machine openings revealed extensive arcing between the striplines feeding rf current to the antenna straps, in a direction along the tokamak edge magnetic field. The September-December, 2000, operating period indicated that an effective stripline voltage limit of $\sim 15-20 \mathrm{kV}$ limited the antenna heating power to $\sim 2.5 \mathrm{MW}$. The striplines had been designed with $\mathbf{E} \| \mathbf{B}$ in order to utilize the central mechanical support septum electrically as well and achieve maximum 
compactness, but a redesign was made during the January-April, 2001, opening, which was able to reorient the striplines to an $\mathbf{E} \perp \mathbf{B}$ configuration and increase all high voltage gaps in order to reduce local electric fields.

\section{BACKPLANE-WALL INTERACTIONS}

Arcing was observed from the antenna backplane to the vacuum vessel during the July, 2000, opening, although both components are nominally at ground potential. Again the inductance of parts of the antenna structure allowed sufficient rf voltage to develop as the result of induced currents to generate arcs in the edge plasma. Anomalously high loading was observed in the operating period prior to this opening. The loading as well as low heating efficiency were observed during full 4-strap antenna operation, but were absent when the outer two straps were grounded and only the center two straps were energized. One possible explanation for these observations was rf power leakage through the backplane induced voltages to the edge plasma. The top and bottom edges of the antenna backplane were shorted to the vacuum vessel with stainless steel sheets, while the ends were shorted with multiple arrays of ceramic capacitors mounted in the vacuum, in order to avoid disruption current damage. This modification did not influence the observed heating efficiency.

\section{PHASING ISSUES}

After iterations and corrections in the phasing instrumentation and external resonant loop modeling, the 4-strap antenna heating efficiency was finally brought up to the same level as the older two 2-strap antennas by compensating for the additional, although short, length of feed stripline to the outer two straps, as compared to the inner two straps. This improvement was determined and implemented during the September-December, 2000, operation.

\section{FAULT DETECTOR ISSUES}

Each machine opening had revealed extensive internal antenna arcing, with arc pitting appearing to be the result of $\mathrm{kJ}$ faulting. Arc detector thresholds, based on the ratio of reflected to forward power, were continually checked and periodically lowered, bur arc damage continued. An increase in the digitization rate of power waveforms to $1 \mathrm{MHz}$ during arcs at the end of the SeptemberDecember, 2000, operation indicated a very slow $(\sim 0.25 \mathrm{~ms})$ rise in reflected power during an arc under plasma operation, suggesting that the antenna circuit has been loaded to a low $\mathrm{Q}$ state by the plasma coupling. Changes in the voltage phase signals were found to be fast $(\mu \mathrm{s})$ however, and appropriate channels have been added to the transmitter block gates. 


\section{UPGRADE CHRONOLOGY}

1. Installed low inductance electrical connection between tile backing plates to eliminate arcing between plates (1-3/2000).

2. Protected ceramic washer assembly at ends of Faraday screen with stainless steel cups to eliminate arc damge from current straps (1-3/2000).

3. RF-bypassed ends of antenna backplane to eliminate arcing to vacuum vessel (7-8/2000).

4. Replaced molybdenum protection tiles with boron nitride to reduce metallic impurity influx (7-8/2000).

5. Aligned protection tiles and modified fastener assembly (7-8/2000, 1-3/2001).

6. Adjusted resonant loops for proper current strap phasing (9-10/2000).

7. Improved and expanded arc protection circuitry (1-3/2000, 10/2000, 1-4/2001).

8. Installed central boron nitride septum to reduce electric field along magnetic field lines in front of antenna (1-3/2001).

9. Rotated feed striplines to reorient $\mathbf{E} \perp \mathbf{B}(1-3 / 2001)$.

10. Increased stripline spacing from $1.0 \mathrm{~cm}$ to $1.5 \mathrm{~cm}$ to reduce electric field (13/2001).

11. Increased clearance of stripline to current strap feedthrough to reduce local electric field (1-3/2001).

12. Added $\mathbf{B}$ probes to monitor antenna strap current balance (1-3/2001).

13. Added ability to monitor pressure behind antenna (1-3/2001).

14. Added ability to monitor arc light behind antenna (1-3/2001).

\section{ANTENNA PERFORMANCE SUMMARY}

C-Mod has presented a challenge to install a high power ( 4 MW) 4-strap ICRF antenna in a tight space. There exists high edge neutral pressure, $0.1-1$ mTorr, and four $1 \mathrm{MW}$ feed lines have been passed through a $20 \mathrm{~cm}$ wide port. In 1999 initial operation was limited by severe arcing and metallic impurity influx to 1.3 MW. During 4-7/2000 operation power came up to $2.5 \mathrm{MW}$, but abnormal loading was detected, and heating efficiency was found to be low when configured as a 4-strap antenna. During the 9-12/2000 operation power came up to $2.5 \mathrm{MW}$ with efficient heating in both 2-strap and 4-strap configurations, but ultimate performance was limited by plasma-rf interactions in front of the antenna and stripline arcing behind the antenna. Major upgrades were performed 1$3 / 2001$, and operation is presently starting again.

\section{ACKNOWLEDGEMENTS}

Work supported by US DoE Contract DE-AC02-76-CH0-3073 and Cooperative Agreement DE-FC02-99ER54512. 


\section{External Distribution}

Plasma Research Laboratory, Australian National University, Australia

Professor I.R. J ones, Flinders University, Australia

Professor J oão Canalle, Instituto de Fisica DEQ/IF - UERJ , Brazil

Mr. Gerson O. Ludwig, Instituto Nacional de Pesquisas, Brazil

Dr. P.H. Sakanaka, Instituto Fisica, Brazil

The Librarian, Culham Laboratory, England

Library, R61, Rutherford Appleton Laboratory, England

Mrs. S.A. Hutchinson, JET Library, England

Professor M.N. Bussac, Ecole Polytechnique, France

Librarian, Max-Planck-Institut für Plasmaphysik, Germany

J olan Moldvai, Reports Library, MTA KFKI-ATKI, Hungary

Dr. P. Kaw, Institute for Plasma Research, India

Ms. P.J . Pathak, Librarian, Insitute for Plasma Research, India

Ms. Clelia De Palo, Associazione EURATOM-ENEA, I taly

Dr. G. Grosso, Instituto di Fisica del Plasma, Italy

Librarian, Naka Fusion Research Establishment, J AERI, J apan

Library, Plasma Physics Laboratory, Kyoto University, J apan

Research Information Center, National Institute for Fusion Science, J apan

Dr. O. Mitarai, Kyushu Tokai University, J apan

Library, Academia Sinica, Institute of Plasma Physics, People's Republic of China

Shih-Tung Tsai, Institute of Physics, Chinese Academy of Sciences, People's Republic of China

Dr. S. Mirnov, TRINITI, Troitsk, Russian Federation, Russia

Dr. V.S. Strelkov, Kurchatov Institute, Russian Federation, Russia

Professor Peter Lukac, Katedra Fyziky Plazmy MFF UK, Mlynska dolina F-2, Komenskeho Univerzita, SK-842 15 Bratislava, Slovakia

Dr. G.S. Lee, Korea Basic Science Institute, South Korea

Mr. Dennis Bruggink, Fusion Library, University of Wisconsin, USA

Institute for Plasma Research, University of Maryland, USA

Librarian, Fusion Energy Division, Oak Ridge National Laboratory, USA

Librarian, Institute of Fusion Studies, University of Texas, USA

Librarian, Magnetic Fusion Program, Lawrence Livermore National Laboratory, USA

Library, General Atomics, USA

Plasma Physics Group, Fusion Energy Research Program, University of California at San Diego, USA

Plasma Physics Library, Columbia University, USA

Alkesh Punjabi, Center for Fusion Research and Training, Hampton University, USA

Dr. W.M. Stacey, Fusion Research Center, Georgia Institute of Technology, USA

Dr. J ohn Willis, U.S. Department of Energy, Office of Fusion Energy Sciences, USA

Mr. Paul H. Wright, Indianapolis, Indiana, USA 
The Princeton Plasma Physics Laboratory is operated by Princeton University under contract with the U.S. Department of Energy.

\author{
Information Services \\ Princeton Plasma Physics Laboratory \\ P.O. Box 451 \\ Princeton, NJ 08543
}

Phone: 609-243-2750

Fax: 609-243-2751

e-mail: pppl_info@pppl.gov

Internet Address: http://www.pppl.gov 